\title{
Povezanost tjelesne aktivnosti i kvalitete života starijih osoba
}

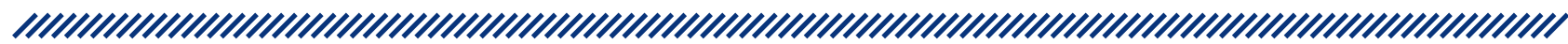

1 Nada Pjevač

2 Tomislav Benjak

3 Neda Pjevač

1 Dom zdravlja Zagreb - Centar, Zagreb

2 Hrvatski zavod za javno zdravstvo, Zagreb

3 Škola narodnog zdravlja „Dr Andrija Štampar”, Zavod za nastavnu tehnologiju, Zagreb

\section{Sažetak}

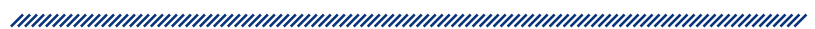

Cilj je istraživanja ispitati povezanost tjelesne aktivnosti i kvalitete života starijih osoba. Ispitanici su pokretni građani starije životne dobi od 70 do 90 godina $(N=100)$. Rezultati su dobiveni na temelju ispunjenog Indeksa osobne kvalitete života. Ispitanici su podijeljeni u dvije skupine s obzirom na učestalost bavljenja tjelesnom aktivnošću. U skupinu aktivnih svrstani su oni koje se bave tri ili više puta tjedno nekom od tjelesnih aktivnosti dulje od 30 minuta ( $N=56)$, a u skupinu neaktivnih oni koji nisu tjelesno aktivni $(\mathrm{N}=44)$.

Utvrđena je niska, ali značajna pozitivna korelacija učestalosti bavljenja tjelesnom aktivnošću i kvalitete života na domeni zdravlja $(r=0,202 ; p<0,05)$ i kvalitete života na domeni uspješnosti $(r=0,198 ; p<0,05)$. Slijedeći preporuke Svjetske zdravstvene organizacije i rezultate niza istraživanja te dijela rezultata i ovog istraživanja koje ukazuje na znatnu povezanost učestalosti tjelesne aktivnosti i domene zdravlja kvalitete života, stalna tjelesna aktivnost mora biti neizostavna mjera primarne prevencije zaštite zdravlja starijih osoba, iako rezultati ovog istraživanje ne ukazuju na statistički značajnu povezanost tjelesne aktivnosti i ukupne kvalitete života.

Ključne riječi: tjelesna aktivnost, kvaliteta života, starije osobe

Datum primitka: 18.5.2019.

Datum prihvaćanja: 1.9.2019.

DOI: $10.24141 / 1 / 5 / 2 / 2$

Adresa za dopisivanje:

Tomislav Benjak

A: Hrvatski zavod za javno zdravstvo, Zagreb

E-mail: tomislav.benjak@hzjz.hr 


\section{Uvod}

Prema definiciji Svjetske zdravstvene organizacije (SZO), starije su osobe u dobi od 60 do 75 godina, stare su osobe u dobi od 76 do 90 godina, a veoma stare osobe su osobe iznad 90 godina. ${ }^{1} \mathrm{U}$ posljednjih 160 godina ljudski se vijek produljio prosječno za 40 godina i dalje se produljuje prosječno za tri mjeseca godišnje. Uslijed toga te zbog smanjenja nataliteta mijenja se demografska slika društva, tako da u ukupnoj populaciji razvijenih zemljama, pa i u Hrvatskoj, postoji sve veći udio starijih osoba. ${ }^{2}$ Prema popisima stanovništva, u Hrvatskoj je 1961. godine bilo 6,2 \% stanovnika starijih od 65 godina, 1971. 8,3\%, a popisom stanovništva 1991. godine utvrđeno je da Hrvatska ima 628000 osoba starijih od 65 godina ili $13,3 \%$ pučanstva. ${ }^{3}$ Prema popisu stanovništva iz 2011. godine u Hrvatskoj živi 4284889 stanovnika. Broj osoba u dobi od 65 i više godina bio je 758633 , odnosno 17,7 \% ukupne populacije, ${ }^{3}$ što Hrvatsku prema kriterijima Ujedinjenih naroda (UN) svrstava među države s vrlo starim pučanstvom. Prema podacima Zaklade UN-a za stanovništvo (UNPF), objavljenima u izvješću pod nazivom Starenje u 21. stoljeću: uspjeh i izazov, 4 svijet će u sljedećih deset godina dostići brojku od milijardu ljudi u dobi od 60 i više godina i morat će se bolje pripremiti za demografsko starenje. Pod tim pojmom podrazumijeva se porast broja i povećanje udjela stanovništva starijega od 60 (ili 65) godina u ukupnom stanovništvu. ${ }^{4}$ Po udjelu populacije starijih od 65 godina u ukupnom broju stanovnika Hrvatska s 15,7 \% zauzima visoko 8. mjesto u Europi iza Italije, Grčke, Švedske, Belgije, Španjolske, Njemačke i Francuske. ${ }^{5}$ Ovim udjelom starijeg stanovništva u ukupnoj populaciji Hrvatska je iznad prosjeka zemalja Europske unije (17\%). Navedeni demografski pokazatelji govore da je Hrvatska zakoračila u „demografsku starost”. Kako bi se starijim osobama, koje su u sustavu socijalne skrbi prepoznate kao posebno osjetljiva kategorija korisnika, omogućilo pravo na dostojanstvenu starost i trajnu društvenu uključenost, potrebna je uspostava cjelovitog pristupa i dugoročne strategije socijalne skrbi. U tu svrhu Ministarstvo za demografiju, obitelj, mlade i socijalnu politiku izradilo je Strategiju socijalne skrbi za starije osobe u Republici Hrvatskoj za razdoblje od 2014. do 2016. čiji je jedan od osnovnih ciljeva i razvoj socijalnih usluga koje pridonose poboljšanju kvalitete života starijih osoba. ${ }^{6}$

Pitanje čimbenika osobne kvalitete života vrlo je aktualno u zadnjem desetljeću kako na području psihologije tako i na području filozofije, socijalnih znanosti, kliničke medicine i zdravstvene zaštite kroničnih bolesnika, ali i otvorene populacije. Danas postoji niz teorija i definicija kvalitete života te upitnika za njezino određivanje. SZO definira kvalitetu života kao pojedinčevu percepciju pozicije u specifičnom kulturološkom, društvenom te okolišnom kontekstu. ${ }^{7}$ Prema definiciji članova skupine International Wellbeing Group, ${ }^{8}$ kvaliteta života je multidimezionalan pojam koji čine: životni standard, zdravlje, produktivnost, mogućnost ostvarivanja bliskih kontakata, sigurnost, pripadanje zajednici te osjećaj sigurnosti u budućnost. Zadovoljavanje potreba te ostvarivanja interesa, vlastitih izbora, vrijednosti i težnji na različitim područjima i u različitim razdobljima života podrazumijevaju navedeni pojam. Hrvatska bi zasigurno trebala imati znanstveno utemeljene činjenice u koje bi socijalne usluge trebala ulagati sredstva kojima bi se poboljšala kvaliteta života starijih osoba. Prema podacima većine znanstvenih istraživanja, tjelesna je aktivnost način za unaprjeđenje kvalitete života starijih, no u određenom manjem broju istraživanja o tome postoje različita stajališta i rezultati. ${ }^{9}, 10$ Prema podacima koje iznosi Center of Disease Control and Prevention $(C D C)$, redovita tjelesna aktivnost jedna je od najvažnijih stvari koja se može učiniti za svoje zdravlje. Tjelesna aktivnost pomaže u kontroli tjelesne težine, smanjenju rizika od kardiovaskularnih bolesti, dijabetesa tipa 2 i metaboličkog sindroma te nekih oblika malignih bolesti. Redovitom tjelesnom aktivnošću jačaju se kosti i mišići, poboljšava se mentalno zdravlje i raspoloženje te se poboljšava sposobnost za obavljanje svakodnevnih aktivnosti, a time se povećavaju šanse za dulji životni vijek. ${ }^{11} \mathrm{U}$ svjetlu tih širokih društvenih izazova koji prate trenutačne globalne trendove starenja, kao što su cijene i dostupnost zdravstvene zaštite, pretilost i bolesti kao posljedice pretilosti, stanovanje te potrebe odraslih koje im zajednica može osigurati, znanstvenici i političari usmjereni su na identificiranje faktora koji mogu imati znatne pozitivne učinke na proces starenja, kao i kvalitetu života starijih osoba. Jedan je od tih faktora redovita tjelesna aktivnost. ${ }^{12-14} \mathrm{~S}$ druge strane, prema Rejeskiju, došlo je do povećanja istraživanja s kliničkim osvrtom na učinke koje tjelesna aktivnost ima na kvalitetu života starijih osoba, ali postoji nedostatak dosljednosti koji ograničava upotrebu toga pojma. Kao rezultat toga pokušava se istražiti što uzrokuje promjene u kvaliteti života, ali su dobiveni rezultati ograničeni. ${ }^{9}$

Cilj je ovog istraživanja ispitati povezanost tjelesne aktivnosti i kvalitete života starijih osoba. 


\section{Ispitanici i metode}

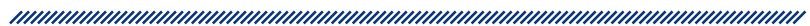

Ispitanici su građani Zagreba u dobi od 70 do 90 godina. Istraživanjem je obuhvaćeno 100 pokretnih ispitanika koji su bili u posjetu obiteljskom liječniku Doma zdravlja Zagreb Centar. Nakon što je dobivena suglasnost etičkog povjerenstva Doma zdravlja za anketiranje pacijenata u čekaonici, ispitanicima je objašnjeno čemu služi anketa te je tražena usmena suglasnost da ispune anketni upitnik Indeksa osobne kvalitete života.

Za mjerenje kvalitete života primijenjen je upitnik Personal wellbeing index (PWI) za odrasle autora Roberta A. Cumminsa i skupine International Wellbeing Group (2006)..$^{15}$ Instrument se sastoji iz osam skala Likertovog tipa kojima se mjeri zadovoljstvo kvalitetom života, pri čemu se subjektivna kvaliteta života po domenama procjenjuje na skali od 0 do $10 \mathrm{~s}$ definiranim krajnjim točkama. Vrijednosti se kreću od 0 (sasvim nezadovoljan) do 10 (sasvim zadovoljan). Upitnik PWI zahvaća sedam dimenzija subjektivne kvalitete života:

1. materijalno blagostanje

2. zdravlje

3. postignuća

4. međuljudske odnose (bliske odnosi s drugim osobama, prijateljima i/ili obitelji)

5. sigurnost (osjećaj sigurnosti)

6. zajednicu (povezanost i pripadnost zajednici)

7. sigurnost u budućnost.

U svrhu dobivanja rezultata koji se jednostavno mogu međusobno usporediti, originalne se vrijednosti transformiraju u standardizirani oblik te se prikazuju u formi „postotka skalnog maksimuma” (\%SM), što daje procjenu kvalitete života na bodovnoj skali od 0 do 100. Ista konverzija ne mijenja statističke značajke podataka, budući da je postupak jednostavna linearna konverzija, ali ima tu prednost da se podaci iz PWI-ja i drugih skala mogu izravno usporediti u smislu središnjih vrijednosti i standardnih devijacija. U ovom istraživanju konverzija PWI bodova koji su dobiveni iz skale od 0 do 10 postiže se jednostavnim pomicanjem decimalne točke udesno. Na primjer, rezultat 7 postaje $70 \%$ SM ili središnji rezultat 6,56 postaje $65,6 \%$ SM. Podaci dobiveni iz pitanja PWI skale mogu se upotrijebiti na razini pojedinačnih domena ili se rezultati po domenama mogu sumirati, a njihov prosjek izračunati radi utvrđivanja indeksa osobnog blagostanja. Metodološka utemeljenost koja je pratila razvoj PWI-ja uz dobre metrijske karakteristike indeksa te njegova pozitivna internacionalna reputacija razlog su uvrštavanja navedenog indeksa u ovo istraživanje.

\section{Rezultati}

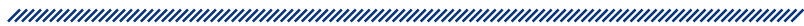

Istraživanjem je obuhvaćeno 100 osoba u dobi od 70 do 90 godina, prosječne dobi 75,34 god. (+/-4,36 god.), pri čemu je bilo 49 ispitanika ženskog i 51 muškog spola. Prikupljen je i podatak o broju kroničnih bolesti od kojih boluju. Ukupan broj kroničnih bolesti kretao se od 0 do 5. Prosjek za skupinu iznosi 2,35 $+/-1,20$ bolesti. Za muške osobe $2,47+/-1,05$, a za žene $2,22+/-1,34$. Nema statistički značajne razlike po spolu u broju kroničnih bolesti (tablica 1$)$.

\begin{tabular}{|c|c|c|c|c|}
\hline \multicolumn{5}{|c|}{$\begin{array}{c}\text { Tablica 1. Raspodjela po dobi i broju } \\
\text { kroničnih bolesti kod ispitanika }\end{array}$} \\
\hline \multirow{2}{*}{} & & \multicolumn{3}{c|}{ spol } \\
\hline \multirow{2}{*}{ dob } & M & 75,71 & 74,96 & 75,34 \\
\hline & SD & 4,70 & 3,99 & 4,36 \\
\hline \multirow{2}{*}{} & minimum & 70 & 70 & 70 \\
\hline \multirow{2}{*}{ kronične } & maksimum & 90 & 86 & 90 \\
\hline bolesti & M & 2,47 & 2,22 & 2,35 \\
\cline { 2 - 5 } (broj) & minimum & 1,05 & 1,34 & 1,20 \\
\cline { 2 - 5 } & maksimum & 5 & 0 & 0 \\
\hline
\end{tabular}

Ukupni indeks kvalitete života ispitanika iznosi 57 \%SM i nalazi se ispod normativnog raspona pretpostavljenog teorijom homeostaze (60 - $80 \%$ SM). Nije utvrđena statistički značajna razlika po spolu u ukupnoj kvaliteti života ni po domenama (tablica 2).

Ispitanici su podijeljeni u dvije skupine s obzirom na učestalost bavljenja tjelesnom aktivnošću. U skupinu aktivnih svrstani su oni koje se bave tri ili više puta tjedno nekom od tjelesnih aktivnosti dulje od 30 minuta ( $N=56$ ), a u skupinu neaktivnih oni koji nisu tjelesno aktivni ( $=44)$ (tablica 3). 


\begin{tabular}{|c|c|c|c|c|}
\hline Domene & & svi & muški & ženski \\
\hline \multirow{2}{*}{$\begin{array}{l}\text { životni } \\
\text { standard }\end{array}$} & M & 47,20 & 48,63 & 45,71 \\
\hline & SD & 21,61 & 20,00 & 23,27 \\
\hline \multirow{2}{*}{ zdravlje } & M & 48,00 & 50,78 & 45,10 \\
\hline & SD & 19,59 & 18,20 & 20,73 \\
\hline \multirow{2}{*}{ uspješnost } & M & 46,90 & 46,86 & 46,94 \\
\hline & SD & 21,35 & 19,13 & 23,65 \\
\hline \multirow{2}{*}{$\begin{array}{l}\text { bliski } \\
\text { odnosi }\end{array}$} & M & 81,70 & 81,76 & 81,63 \\
\hline & SD & 18,43 & 17,52 & 19,51 \\
\hline \multirow{2}{*}{ sigurnost } & M & 51,20 & 53,14 & 49,18 \\
\hline & SD & 23,19 & 22,67 & 23,79 \\
\hline \multirow{2}{*}{$\begin{array}{l}\text { pripadnost } \\
\text { zajednici }\end{array}$} & M & 80,10 & 79,41 & 80,82 \\
\hline & SD & 18,06 & 17,37 & 18,91 \\
\hline \multirow{2}{*}{$\begin{array}{l}\text { sigurnost u } \\
\text { budućnost }\end{array}$} & M & 44,00 & 45,88 & 42,04 \\
\hline & SD & 19,95 & 18,46 & 21,41 \\
\hline \multirow{4}{*}{$\begin{array}{l}\text { Indeks } \\
\text { kvalitete } \\
\text { života } \\
\text { PWI }\end{array}$} & $M$ & 57,01 & 58,07 & 55,92 \\
\hline & SD & 13,91 & 12,45 & 15,34 \\
\hline & minimum & 27,14 & 30,00 & 27,14 \\
\hline & maksimum & 95,71 & 85,71 & 95,71 \\
\hline
\end{tabular}

Nije utvrđena statistički značajna razlika u ukupnoj kvaliteti života ni po domenama s obzirom na bavljenje tjelesnom aktivnošću (tablica 3).

Utvrđivana je također korelacija i značajnost povezanosti indeksa kvalitete života i učestalosti bavljenja tjelesnom aktivnošću, pri čemu nije utvrđena značajna povezanost između učestalosti bavljenja tjelesnom aktivnošću i ukupne kvalitete života, kao ni tjelesne aktivnosti u odnosu na broj kroničnih bolesti. Međutim, utvrđena je statistički značajna negativna povezanost ukupne kvalitete života i broja kroničnih bolesti od kojih ispitanici boluju (tablica 4).

Osim korelacije i značajnosti povezanosti indeksa kvalitete života i učestalosti bavljenja tjelesnom aktivnošću, utvrđivana je i korelacija i značajnost povezanosti domena kvalitete života i učestalosti bavljenja tjelesnom aktivnošću.

\begin{tabular}{|c|c|c|c|c|}
\hline Domene & $\begin{array}{c}\text { skupina } \\
\text { prema } \\
\text { bavljenju } \\
\text { tjelesnim } \\
\text { aktivnostima }\end{array}$ & $\mathrm{N}$ & $\mathrm{M}$ & SD \\
\hline \multirow{2}{*}{ dob } & ne bavi se & 44 & 76,09 & 4,142 \\
\hline & bavi se & 56 & 74,75 & 4,473 \\
\hline \multirow{2}{*}{$\begin{array}{l}\text { životni } \\
\text { standard }\end{array}$} & ne bavi se & 44 & 48,18 & 23,945 \\
\hline & bavi se & 56 & 46,43 & 19,765 \\
\hline \multirow{2}{*}{ zdravlje } & ne bavi se & 44 & 45,68 & 20,731 \\
\hline & bavi se & 56 & 49,82 & 18,634 \\
\hline \multirow{2}{*}{ uspješnost } & ne bavi se & 44 & 43,86 & 22,122 \\
\hline & bavi se & 56 & 49,29 & 20,614 \\
\hline \multirow{2}{*}{$\begin{array}{l}\text { bliski } \\
\text { odnosi }\end{array}$} & ne bavi se & 44 & 81,14 & 20,934 \\
\hline & bavi se & 56 & 82,14 & 16,372 \\
\hline \multirow{2}{*}{ sigurnost } & ne bavi se & 44 & 54,09 & 27,136 \\
\hline & bavi se & 56 & 48,93 & 19,510 \\
\hline \multirow{2}{*}{$\begin{array}{l}\text { pripadnost } \\
\text { zajednici }\end{array}$} & ne bavi se & 44 & 78,64 & 19,119 \\
\hline & bavi se & 56 & 81,25 & 17,275 \\
\hline \multirow{2}{*}{$\begin{array}{l}\text { sigurnost u } \\
\text { budućnost }\end{array}$} & ne bavi se & 44 & 43,86 & 22,947 \\
\hline & bavi se & 56 & 44,11 & 17,454 \\
\hline \multirow{2}{*}{$\begin{array}{l}\text { Indeks } \\
\text { kvalitete } \\
\text { života }\end{array}$} & ne bavi se & 44 & 56,49 & 16,249 \\
\hline & bavi se & 56 & 57,42 & 11,891 \\
\hline
\end{tabular}

\begin{tabular}{|c|c|c|c|}
\hline & & $\begin{array}{c}\text { tjelesna } \\
\text { aktivnost } \\
\text { (koliko puta } \\
\text { tjedno) }\end{array}$ & $\begin{array}{c}\text { Indeks } \\
\text { kvalitete života } \\
\text { (PWI) }\end{array}$ \\
\hline \multirow{2}{*}{$\begin{array}{l}\text { kronične } \\
\text { bolesti } \\
\text { (broj) }\end{array}$} & $r$ & $-0,143$ & $-0,586$ \\
\hline & $\mathrm{p}$ & 0,156 & $0,000^{\star *}$ \\
\hline \multirow{2}{*}{$\begin{array}{l}\text { Indeks } \\
\text { kvalitete života } \\
\text { (PWI) }\end{array}$} & $r$ & 0,068 & \\
\hline & $p$ & 0,500 & \\
\hline
\end{tabular}




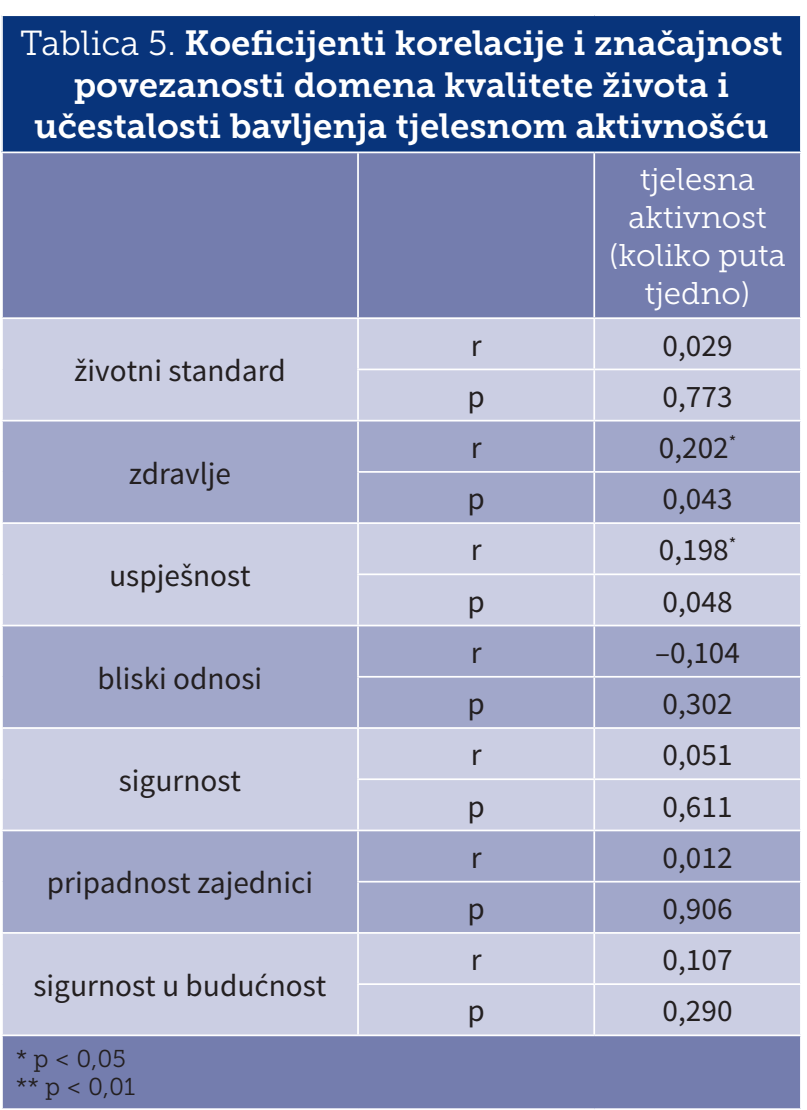

Utvrđena je niska, ali značajna pozitivna korelacija učestalosti bavljenja tjelesnom aktivnošću i kvalitete života u domeni zdravlja $(r=0,202 ; p<0,05)$ i kvalitete života u domeni uspješnosti $(r=0,198 ; p<0,05)$.

\section{Rasprava}

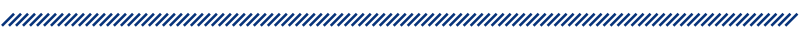

Većina svih dostupnih istraživanja ukazuje na pozitivan učinak tjelesne aktivnosti na kvalitetu života starijih osoba. ${ }^{11-14} \mathrm{~S}$ druge strane, rezultati ovog istraživanja ukazuju da ne postoji statistička značajna povezanost tjelesne aktivnosti i ukupne kvalitete života, no ipak je prisutna značajna pozitivna korelacija učestalosti bavljenja tjelesnom aktivnosti i kvalitete života u domeni zdravlja. Ovakva odstupanja, u odnosu na većinu istraživanja koja naglašavaju važnost tjelesne aktivnosti za unaprjeđenje kvalitete života starijih osoba, može se protumačiti izrazito niskom kvalitetom života kod cijele ispitivane populacije. Naime, istraživanjem je utvrđeno da je kvaliteta života 57 \%SM što je ispod prosjeka kvalitete života u Hrvatskoj. ${ }^{16}$ Prema teoriji homeostaze, ${ }^{17}$ ako kvaliteta života padne ispod $60 \%$ SM, dolazi do narušavanja homeostaze i razvoja depresivnih simptoma te narušavanja psihofizičkog zdravlja pojedinca. Moguće je da upravo ovakva narušena homeostaza do situacije da redovita tjelesna aktivnost nema pozitivnu korelaciju s kvalitetom života. Razlozi ovakvoj niskoj percepciji kvalitete života zasigurno leže u i trenutačnom stanju u hrvatskom društvu. Prema istraživanju UNDP-a (United Nations Development Programme) o kvaliteti života i rizika od socijalne isključenosti, ${ }^{18}$ četvrtina hrvatskih kućanstava primila je neki oblik socijalne pomoći u proteklom periodu. Vlastitim životnim standardom nezadovoljan je bio svaki peti građanin. Desetini kućanstava nedostajalo je novca za hranu, a podjednaki broj kućanstava imao je poteškoća s održavanjem svojeg doma odgovarajuće toplim. Svako peto kućanstvo bilo je u dugovima, odnosno u nemogućnosti platiti na vrijeme smještaj ili režije. ${ }^{18} \mathrm{U}$ ovom istraživanju ispitanici su posebice bili nezadovoljni upravo životnim standardom, postignućima i osjećajem sigurnosti. Istraživanja također pokazuju da stanovnici Hrvatske imaju nižu kvalitetu života od ostalih stanovnika država EU-a. ${ }^{19}$ Kao potvrda ove teze mogu poslužiti i činjenice da se pozitivna korelacija kvalitete života i tjelesne aktivnosti nalazi većinom u znanstvenim istraživanjima ekonomski razvijenih zemalja pa bi bilo važno ovakvo istraživanje provesti i u zemljama s nižim BDP-om. Segment je ovog istraživanja koji ukazuje da je tjelesna aktivnost ipak važna u starijoj životnoj dobi utvrđena značajna pozitivna korelacija učestalosti bavljenja tjelesnom aktivnošću i kvalitete života u domeni zdravlja. Ispitanici koji su redovito i češće tjelesno aktivni statistički su značajno procijenili svoje zdravlje boljim od kontrolne skupine tjelesno neaktivnih osoba. Upravo ovaj rezultat, uz niz međunarodnih istraživanja, trebao bi biti znanstvena potpora Ministarstvu za demografiju, obitelj, mlade i socijalnu politiku da razvija socijalne usluge usmjerene na organizaciju tjelovježbe primjerene za osobe starije životne dobi, s obzirom na podatke o uključivanju osoba starije dobi u rekreativne programe. Na 1. hrvatskom savjetovanju o tjelesnom vježbanju osoba starije dobi održanome u Krku 2003. godine iznesena je procjena da u organiziranim skupinama u Hrvatskoj vježba oko 2000 ljudi starijih od 65 godina što iznosi svega $0,3 \%$ starije populacije. ${ }^{20}$ Znanstvena istraživanja i teorijske rasprave imaju smisla samo ako su polazište za konkretne akcije. Potrebno je što više propagirati različite aktivnosti za starije, kroz medije $\mathrm{i}$ uz pomoć stručnjaka različitih profila te ponuditi što više raznolikih sadržaja. Pokretanje Nacionalnog progra- 
ma Ministarstva zdravstva „Živjeti zdravo” s posebnim naglaskom na tjelesnu aktivnost također je prilika da se unaprijedi aspekt tjelesne aktivnosti kod osoba starije životne dobi.

\section{Zaključak}

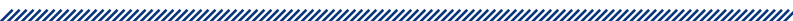

Slijedeći preporuke SZO-a i rezultate niza istraživanja te dijela rezultata i ovog istraživanja koje ukazuje na značajnu povezanost učestalosti tjelesne aktivnosti i domene zdravlja kvalitete života, stalna tjelesna aktivnost mora biti neizostavna mjera primarne prevencije zaštite zdravlja starijih osoba, iako rezultati ovog istraživanje ne ukazuju na statistički značajnu povezanost tjelesne aktivnosti i ukupne kvalitete života. To zahtijeva sveobuhvatniju javnozdravstvenu akciju usmjerenu na poticanje tjelesne aktivnosti starijih osoba, ali i organiziranje sadržaja koji će to omogućiti.

\section{Referencije}

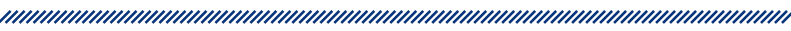

1. Papalia D, Wendkos O, Feldman R. Human development. New York: McGrawHill; 1992.

2. Lepan Ž, Leutar, Z. Važnost tjelesne aktivnosti u starijoj životnoj dobi. Socijalna ekologija.2012; 21(2): 203-224.

3. Državni zavod za statistiku. Popisi stanovništva [internet] Zagreb: 2019. Dostupno na: https://www.dzs.hr/

4. UNFPA and HelpAge International. Aging in the twentyfirst century. New York: United Nations Population Fund; 2012.

5. UNDP. Izvješće o društvenom razvoju Hrvatska 2006. Neumreženi: lica socijalne isključenosti u Hrvatskoj. Zagreb: Program Ujedinjenih naroda za razvoj, Hrvatska; 2007.

6. Ministarstvo socijalne politike i mladih. Strategija socijalne skrbi za starije osobe u Republici Hrvatskoj za razdoblje [internet] Zagreb: 2014. Dostupno na: https://vlada.gov.hr/UserDocsImages//ZPPI/Strategije\%20-\%20 OGP/socijalna\%20politika//strategija\%20socijalne $\% 20$ skrbi\%20za\%20starije\%2014-2-14\%5B1\%5D.pdf

7. Development of the World Health Organization WHOQOLBREF Quality of Life Assessment. Psychological medicine. 1998; 28(3): 551-558.
8. Cummins B. International Society for Quality of Life Studies. Quality of life definition and terminology: a discussion document from the International Society for Quality of Life Studies. Berlin: The International Society for Quality-of-Life Studies (ISQOLS); 1998. 1-43.

9. Rejeski WJ, Mihalko SL. Physical activity and quality of life in older adults. The journals of gerontology. 2001; 56 (2): 23-35.

10. McMurdo MET, Burnett L. Randomized controlled trial of exercise in the olderly. Gerontology. 1992; 38(5): 292-298.

11. Centers for Disease Control and Prevention (CDC). Physical activity Guidelines for older adults [internet]: 2019. Dostupno na: https://health.gov/paguidelines/secondedition/pdf/Physical_Activity_Guidelines_2nd_edition. pdf\#page $=66$

12. World Health Organization.The Heidelberg Guidelines for promoting physical activity among older persons. Journal of Aging and Physical Activity. 1997; 5: 1-8.

13. American College of Sports Medicine. ACSM position stand on exercise and physical activity for older adults. Medicine and science in sports and exercise. 1998; 30(6): 992-1008.

14. Sheppar L, Senior J, Park CH, Mockenhaupt R, ChodzkoZajko W, Bazzarre T. The National Blueprint Consensus Conference Summary Report: Strategic priorities for increasing physical activity among adults aged $>50$. American journal of preventive medicine. 2003; 25(3): 209-213.

15. International Wellbeing Group. Personal Wellbeing Index. [internet] Melbourne: 2013. Dostupno na: http:// www.acqol.com.au/uploads/pwi-a/pwi-a-english.pdf

16. Vuletic G. Proceedings of the 8th Australian Conference on Quality of Life. Health related quality of life and satisfaction with life in Croatia. Melbourne: Deakin University; 2006.

17. Cummins R. Proceedings, Second Conference of Quality of Life in Cities. A homeostatic model for subjective quality of life. Singapore: National University of Singapore; 2000. 51-59.

18. United Nations Development Programme. Kvaliteta života u Republici Hrvatskoj i rizik od socijalne isključenosti. Zagreb: UNDP; 2006.

19. Jureša V, Ivanković D, Vuletić G, Babić-Banaszak A, Srček I, Mastilica M, Budak A. The Croatian Health Survey - SF36: I. General Quality of Life Assessment. Collegium Antropologicum. 2000; 24(1): 69-78.

20. Heimer S. Javno-zdravstveni aspekt aktivnog starenja. Glasnik Hrvatskog saveza sportske rekreacije Sport za sve. 2003; 21(33-34): 9-18. 


\section{CORRELATION BETWEEN PHYSICAL ACTIVITY AND THE QUALITY OF LIFE OF OLDER PEOPLE}

1 Nada Pjevač

2 Tomislav Benjak

3 Neda Pjevač

1 Health centre Zagreb - Centre, Zagreb

2 Croatian Institute of Public Health, Zagreb

3 Andrija Štampar Teaching Institute of Public Health Department of Educational Technology, Zagreb domain of quality of life, constant physical activity must be an essential measure of primary health prevention of older people, although the results of this study do not indicate a statistically significant correlation between physical activity and overall quality of life.

\section{Summary}

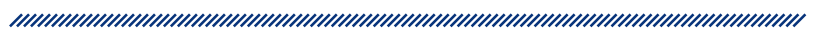

The aim of the study was to investigate the correlation between the physical activity and quality of life of older people. Respondents were movable, older citizens of $70-90$ years $(\mathrm{N}=100)$. Results were obtained on the basis of the completed Quality of Life Index. Participans were divided into two groups considering the frequency of physical activities. In the 'active' group were participants who participated in some sort of physical activity two or three times a week for more than 30 minutes $(n=56)$, and a group of inactive people included participants who were not physically active $(n=44)$. There was a low but significant positive correlation frequency of doing physical activity and quality of life in the domain of health $(r=0.202 ; p<0.05)$ and quality of life in the domain of perfomance $(r=0.198 ; p<0.05)$. In keeping with the recommendations of the World health Organization, a number of research results, and the results of this research, which suggests an important connection between the frequency of physical activity and health
Keywords: physical activity, quality of life, old people 